Jurnal Pakarena

Volume 4 Nomor 1, Juni 2019

e-ISSN: 2550-102X dan p-ISSN: 1693-3990

(c) (1) This work is licensed under a Creative Commons Attribution

4.0 International License

\title{
KELAYAKAN ISI BUKU TEKS SENI BUDAYA KURIKULUM 2013 SMP/MTS KELAS VIII DITINJAU DARI ASPEK PEMBELAJARAN SENI RUPA
}

\section{Syamsualam, Irfan, Sumiati Patimari}

Keywords :

Kelayakan Isi; Buku teks;

Seni Budaya

\section{Corespondensi Author}

Program Studi Pendidikan Seni Rupa, Pascasarjana Universitas Negeri Makassar syamsualam7310@gmail.com

\section{ABSTRAK}

Penelitian ini bertujuan untuk mendeksripsikan kelayakan isi buku teks Seni Budaya (seni rupa) terbitan Pusat Kurikulum dan Perbukuan, Balitbang, Kemendikbud sesuai Badan Standar Nasional Pendidikan (BSNP) . Penelitian ini menggunakan metode penelitian deskriptif. Sumber data pada penelitian ini adalah buku teks pelajaran Seni Budaya untuk SMP/MTs Kelas VIII Kurikulum 2013 terbitan Pusat Kurikulum dan Perbukuan, Balitbang, Kemendikbud.revisi 2017. Berdasarkan hasil analisis instrumen kelayakan isi yang telah ditetapkan oleh BNSP yakni (1) Kesesuain Uraian Materi dengan KI dan KD, (2) Keakuratan Materi, (3) Materi Pendukung Pembelajaran, buku teks terbitan Pusat Kurikulum dan Perbukuan, Balitbang, Kemendikbud 2017 ini dapat dikatakan telah memenuhi syarat kelayakan isi buku teks. Namun dalam hal kelengkapan materi buku teks terbitan Pusat Kurikulum dan Perbukuan, Balitbang, Kemendikbud revisi 2017 ini masih tergolong kurang lengkap. Secara keseluruhan buku teks ini telah memenuhi standar kelayakan isi buku teks.
ABSTRACT
This study aims to describe the feasibility of textbook contents Arts (fine arts) published by the Center for Curriculum and Perbukuan, Research, Kemendikbud appropriate National Education Standards Agency (BSNP). This research uses descriptive method. Sources of data in this research is the Cultural Arts textbooks for SMP / MTs Eighth Grade Curriculum 2013 issue of Curriculum Center and Perbukuan, Research, Kemendikbud.revisi 2017. Based on the analysis of the contents of the instrument feasibility has been established by BNSP namely (1) suitability Material Description with KI and KD, (2) the accuracy of the material, (3) Supplemental Materials Learning, the textbook published by the Center for Curriculum and Perbukuan, Research, Kemendikbud 2017 can be said to have been eligible to the contents of the textbook. But in terms of completeness published textbook material and the Curriculum Center of Books, Research, Kemendikbud 2017 revision is still relatively incomplete. Overall this text has met the eligibility standard text book content. 
Syamsualam, Irfan, Sumiati Patimari, Kelayakan Isi Buku Teks Seni Budaya Kurikulum 2013 SMP/MTS Kelas VIII Ditinjau Dari Aspek Pembelajaran Seni Rupa, hlm. 46-53

\section{PENDAHULUAN}

Mata pelajaran seni budaya merupakan mata pelajaran yang membahas mengenai karya seni estetis, artistik dan kreatif yang berakar pada norma, nilai, prilaku, dan produk seni budaya bangsa melalui aktivitas berkesenian. Untuk memenuhi suatu standar kualitas pendidikan, banyak bermunculan mediamedia pembelajaran yang dapat menunjang hasil proses pendidikan yang bermutu, baik itu sarana maupun prasarana. Pada setiap mata pelajaran yang disajikan pasti membutuhkan bahan ajar berupa buku teks. Buku teks (buku siswa) ini berfungsi sebagai sarana pelaksana kurikulum yang menyajikan sumber ajaran yang bervariasi dan sistematis, mencerminkan suatu sudut pandang tertentu tentang mata pelajaran yang diajarkan, serta menyajikan masalah yang kaya dan serasi. Buku merupakan sumber belajar yang sangat dibutuhkan oleh peserta didik untuk membantunya dalam proses kegiatan belajar. Kehadiran buku teks di lembaga pendidikan yang memang kondisinya sangat kompleks sudah tentu mempunyai nilai tertentu. Nilai buku teks bergantung pada bobotnya, juga pada misi, dan juga fungsinya.

Dalam interaksi belajar-mengajar tidak hanya diperlukan seorang pengajar dan peserta didik, melainkan juga diperlukan sebuah alat pembelajaran. Salah satunya adalah buku teks. Dengan adanya buku teks, guru dan peserta didik akan terbantu dalam memperlancar proses belajar-mengajar. Seorang guru diharapkan memiliki pengetahuan, keterampilan dan sikap kritis terhadap keberadaan buku teks sebagai pendukung kurikulum yang berlaku, yang pengadaannya semakin gencar dilakukan. Tahap selanjutnya, guru dapat mengkaji buku teks dan hubungannya dengan kurikulum sehingga guru tidak hanya sekadar menerima apa saja yang ada dalam buku teks, namun mampu memahami, mengkritisi dengan menelaah buku teks yang pada akhirnya guru mampu menyusun sebuah buku teks sederhana. Paling tidak buku teks tersebut digunakan di lingkungan sekolah yang bersangkutan saja. Buku teks memegang peranan penting dalam pengajaran yang dapat memperlancar aktivitas peserta didik dalam pembelajaran, baik di dalam kelas maupun di luar kelas. Semakin baik kualitas buku teks, maka semakin sempurna pengajaran mata pelajaran yang ditunjang oleh buku teks tersebut, termasuk mata pelajaran Seni Budaya (buku siswa) pada aspek pembelajaran seni rupa. Buku teks Seni Budaya (buku siswa) yang bermutu, jelas akan meningkatkan kualitas pengajaran dan hasil pengajaran Seni Budaya (buku siswa) pada aspek pembelajaran seni rupa.

Pada tahun 2017, penerbit Pusat Kurikulum dan Perbukuan, Balitbang, Kemendikbud menerbitkan buku teks Seni Budaya revisi 2017 untuk SMP/MTs kelas VIII yang ditulis oleh Eko Purnomo, dkk. Buku teks tersebut, telah beredar di tokotoko buku dan digunakan di sekolah pada mata pelajaran Seni Budaya. Bahan ajar berupa buku teks (buku siswa) Seni Budaya untuk SMP/MTs terbitan Pusat 
Kurikulum dan Perbukuan, Balitbang, Kemendikbud tahun 2017 menjadi hal yang perlu dianalisis untuk diketahui kelayakannya, maka peneliti menganggap penting diadakan penelitian. Untuk mengetahui dan mengidentifikasi standar penilaian buku teks pelajaran yang sesuai Badan Standar Nasional Pendidikan (BSNP), sehingga buku teks layak untuk digunakan. Saat ini masih banyak buku teks yang memerlukan penilaian agar memenuhi standar yang ditetapkan. Sebagaimana yang tercantum dalam Undang-undang nomor 20 tahun 2003 tentang Sistem Pendidikan Nasional, pendidikan merupakan kebutuhan yang sangat penting dalam kehidupan, melalui pendidikan manusia belajar,menuntut ilmu dan menggunakan ilmunya untuk menuju kehidupan yang lebih baik. Oleh karena itu, meningkatkan kualitas pendidikan menjadi aspek yang sangat diperhatikan di setiap negara termasuk Indonesia. Menyadari bahwa pendidikan memiliki peranan yang sangat penting bagi proses pembelajaran yang berkualitas. Upaya yang telah dilakukan tersebut diantaranya memperbaiki kurikulum, memperbaiki sarana dan prasarana penunjang pendidikan, menggunakan media pembelajaran yang sesuai, meningkatkan kemampuan para pendidik dan menggunakan strategi pembelajaran yang baik. Sebagai salah satu faktor yang turut menentukan keberhasilan pendidikan atau proses pembelajaran adalah buku ajar atau buku teks. Buku teks (buku siswa) menjadi pegangan peserta didik sebagai referensi utama atau menjadi buku suplemen/tambahan. Buku teks pelajaran memegang peranan penting dalam proses belajar mengajar di sekolah. Nilai buku teks tergantung pada bobotnya, misi dan fungsinya.Buku ajar yang baik memiliki kriteria atau standar tertentu seperti relevansinya dengan kurikulum yang sedang berlaku saat ini, kesesuaian metode dengan materi yang disampaikan, isi buku atau sudut keilmuannya yaitu apakah teoriteori yang digunakan di dalam penulisan buku ajar tersebut sudah sesuai atau belum dan sebagainya. Adapun upaya mendapatkan buku teks yang baik, diharapkan tuntunan memenuhi sebagaimana yang tertuang dalam Peraturan Menteri nomor 11 pasal 3 ayat 1 tahun 2005 menyatakan bahwa buku teks pelajaran untuk setiap mata pelajaran yang digunakan pada satuan pendidikan dasar dan menengah dipilih dari buku teks pelajaran yang telah ditetapkan oleh menteri berdasarkan rekomendasi penilaian kelayakan dari Badan Standar Nasional Pendidikan (BSNP).

Mengingat buku teks sangat
berperan penting dalam proses pembelajaran, maka buku teks tersebut perlu dianalisis untuk diketahui kelayakan dari buku teks tersebut, maka peneliti menganggap penting diadakan penelitian terhadap buku teks yang telah disebutkan. Dengan demikian gambaran tersebut, menjadi sebuah asumsi awal untuk dapat mengetahui kelayakan buku teks Seni Budaya khusus pada pembelajaran seni rupa kelas VIII. Oleh karena itu, saya tertarik meneliti "kelayakan buku teks Seni Budaya untuk SMP/MTs terbitan Pusat Kurikulum dan Perbukuan, Balitbang, Kemendikbud (studi evaluatif buku teks 
Syamsualam, Irfan, Sumiati Patimari, Kelayakan Isi Buku Teks Seni Budaya Kurikulum 2013 SMP/MTS Kelas VIII Ditinjau Dari Aspek Pembelajaran Seni Rupa, hlm. 46-53

seni budaya (seni rupa) kelas VIII penulis

Eko Purnomo dan kawan-kawan)".

\section{Metode Penelitian}

Evaluasi dilaksanakan untuk menguji objek/kegiatan dengan kriteria tertentu untuk keperluan pembuatan keputusan. Hal ini sejalan dengan tujuan utama penelitian yakni peneliti ingin mengevaluasi dan mengadakan penilaian kelayakan terhadap buku teks yang ditinjau dari segi kelayakan isi dengan mengevaluasi buku teks yang dikaji berdasarkan standar-standar yang telah ditentukan Badan Standar Nasional Pendidikan (BSNP) tentang kelayakan buku teks, untuk selanjutnya dianalisis dan diinterpretasikan. Rancangan penelitian menggunakan teknik analisis isi (content analysis). Penggunaan rancangan analisis isi ini sesuai dengan data penelitian, yakni berupa teks. Analisis isi merupakan suatu analisis mendalam yang dapat menggunakan teknik kuantitatif maupun kualitatif. Dengan demikian, penelitian ini tergolong penelitian evaluatif yang menggunakan analisis isi.

Buku teks Seni Budaya tersebut, sebelumya dinilai oleh validator ahli isi, penyajian dan kegrafikaan. Selanjutnya, hasil validasi data oleh masing-masing validator ahli, dikumpulkan dan disimpulkan secara keseluruhan oleh peneliti dengan menggunakan teori-teori yang relevan dikaitkan dengan standar BSNP, sehingga diketahui bahwa apakah buku tersebut layak atau tidak layak.

\section{Hasil Penelitian}

Buku teks Seni Budaya terbitan Pusat Kurikulum dan Perbukuan, Balitbang, Kemendikbud, memuat empat materi yaitu seni rupa, seni musik, seni tari dan seni teater. Keempat materi tersebut, masing- masing disajikan untuk semester ganjil dan semester genap. Pada buku teks (buku siswa) tersebut di halaman awal tidak tercantum Kompetensi Isi (KI) dan Kompetensi Dasar (KD). Materi semester ganjil pada buku terbitan Pusat Kurikulum dan Perbukuan, Balitbang, Kemendikbud menyajikan dua bab untuk materi seni rupa yaitu: bab 1 Menggambar Model, yang memuat antara lain (a) konsep dan prosedur menggambar model, (b) alat dan bahan menggambar model, (c) teknik menggambar model dan bab 2 Menggambar Ilustrasi yang memuat antara lain (a) menggambar ilustrasi, (b) alat dan bahan, (c) proses menggambar ilustrasi. Kedua materi tersebut sudah mengacu pada KI yang telah ditetapkan sesuai dengan KD. Terdapat empat KI dan empat KD yang terdapat pada Standar Isi untuk mata pelajaran Seni Budaya kelas VIII. Materi seni rupa semester genap pada buku Seni Budaya terbitan Pusat Kurikulum dan Perbukuan, Balitbang, Kemendikbud, ada dua bab yaitu bab 9 Menggambar Poster yang meluputi antara lain (a) konsep membuat poster, (b) syarat membuat poster, (c) alat dan bahan, dan bab 10 Menggambar Komik yang meliputi antara lain (a) konsep menggambar komik, (b) syarat menggambar komik, (c) bahan dan alat menggambar komik. Pada Bab 1, Bab 
2, Bab 9 dan Bab 10 , pada akhir pembelajaran diberikan pelatihan atau evaluasi yakni: latihan yang sifatnya kognitif dan keterampilan. Materi yang disampaikan dalam buku Seni Budaya ini meliputi pengetahuan, keterampilan dan nilai dalam menghasilkan beragam karya seni. Misalnya, menggambar model, ilustrasi, poster dan komik. Materi-materi yang diberikan mengantarkan siswa untuk memiliki pengalaman estetik dalam bentuk kegiatan mengapresiasi dan berekspresi/berkreasi karya seni rupa. Dalam menyampaikan materi seni rupa yang terdapat dalam buku ini, guru dapat menggunakan pendekatan Kontekstual atau Contextual Teaching and Learning (CTL). Dengan demikian pembagian deskripsi secara lengkap, pada akhirnya buku Seni Budaya untuk SMP/MTs kelas VII terbitan Pusat Kurikulum dan Perbukuan, Balitbang, Kemendikbud 2017 dianalisis dengan menggunakan kriteria kelayakan isi.

\section{Pembahasan Kelayakan isi}

Kelayakan isi menyangkut materi apa yang disajikan dalam buku teks. Ada beberapa hal penting yang harus dipenuhi agar buku teks dapat dikatakan memiliki isi yang layak untuk dipakai. Kelayakan isi terlihat dari kesesuain uraian materi dengan Standar kompetensi (KI) dan Kompetensi Dasar (KD), keakuratan materi dan materi pendukung. Adapun yang harus diperhatikan dalam menentukan kelayakan isi adalah:

a. Kesesuaian uraian materi dengan KI dan KD serta cakupan materi

Kesesuain uraian materi dengan KI dan KD. Materi yang termuat dalam buku teks harus jelas dan sesuai dengan KI dan KD yang telah ditetapkan oleh BSNP dalam standar isi. Kesesuain materi ini meliputi kelengkapan atau cakupan materi dan kedalaman materi yang disajikan.

Buku ini tidak memuat Kompetensi Inti (KI) dan Kompetensi Dasar (KD) pada halaman depan, begitu pula pada pembahasan disetiap Bab 1, Bab 2, Bab 9 dan Bab 10 ini tidak ditulis lagi KI dan $\mathrm{KD}$, sehingga tidak nampak Kompetensi Inti dan Kompetensi Dasar apa yang dibahas dan ingin dicapai dalam setiap bab pada aspek pembelajaran seni rupa ini. Tetapi yang tertulis hanya tujuan pembelajaran saja. Jika dilihat dari tujuan pembelajaran serta materi yang dibahas, maka saya dapat menyimpulkan bahwa tujuan pembelajarannya ini sudah sesuai dengan Standar Isi Kurikulum 2013 (K13), sebagai contoh materi pada Bab 1 tentang Menggambar Model semester ganjil (semester 1).

\section{b. Keluasan Materi}

Konsep, definisi, prinsip, prosedur,contohcontoh, dan pelatihan yang terdapat dalam buku teks buku Seni Budaya untuk SMP/MTs kelas VIII terbitan Pusat Kurikulum dan Perbukuan, Balitbang, Kemendikbud 2017 ini, dapat dikatakan bahwa keluasan materi masih perlu diperluas cakupan konten materinya, walaupun pada dasarnya telah sesuai dengan kebutuhan materi pokok yang mendukung tercapainya SK dan KD. Sebagai contoh kita bisa lihat pada bab 2 halaman 17 dengan judul bab "Menggambar Ilustrasi". Pada bab ini materi dimulai dengan menyajikan konsep 
Syamsualam, Irfan, Sumiati Patimari, Kelayakan Isi Buku Teks Seni Budaya Kurikulum 2013 SMP/MTS Kelas VIII Ditinjau Dari Aspek Pembelajaran Seni Rupa, hlm. 46-53

dan dilanjutkan dengan definisi dan contoh-contoh serta pelatihan pelatihan yang mendukung tercapainya Kompetensi Inti dan Kompetensi Dasar.

Buku teks terbitan Pusat Kurikulum dan Perbukuan, Balitbang, Kemendikbud 2017 yang dianalisis ini, telah memuat materi yang menjabarkan subtansi minimal (fakta, konsep, prinsip, dan teori) yang terkandung dalam KI dan KD (dalam kurikulum 2013).

c. Kedalaman Materi

Kedalaman materi sebuah buku teks juga harus diperhatiakan. Harus jelas pembagian kedalaman materi pada tiap tingkatan kelas. Konsep, definisi, prinsip, prosedur, contoh-contoh, dan pelatihan yang terdapat dalam buku teks terbitan Pusat Kurikulum dan Perbukuan, Balitbang, Kemendikbud 2017 ini, dapat dikatakan telah sesuai dengan kebutuhan materi pokok yang mendukung tercapainya KI dan KD (dalam kurikulum 2013).

\section{Keakuratan Materi}

a. Akurasi Konsep dan Definisi

1. Materi dalam buku teks harus disajikan secara akurat untuk menghindari miskonsepsi yang dilakukan siswa. Dalam buku teks terbitan Pusat Kurikulum dan Perbukuan, Balitbang, Kemendikbud 2017 yang dianalisis ini, materi telah disajikan secara akurat dan tidak menimbulkan miskonsepsi yang dilakukan siswa. Hal ini dapat kita lihat pada pada setiap materi yang ditampilkan pada setiap bab. Sebagai contoh dapat kita lihat pada bab 9 dengan judul bab "Menggambar poster". Adapun analisis buku Seni Budaya untuk SMP/MTs kelas VII terbitan Pusat Kurikulum dan Perbukuan, Balitbang, Kemendikbud 2017 dari segi kelayakan isi dengan kesesuaian Kompetensi Inti dan Kompetensi Dasar. Kelas VIII semester ganjil dan genap Pada buku teks seni budaya untuk SMP/MTs kelas VIII terbitan Pusat Kurikulum dan Perbukuan, Balitbang, Kemendikbud 2017, menurut penulis pada bab 1sudah menyajikan kesesuaian materi dengan Kompetensi Inti dan Kompetensi Dasar, namun tidak keseluruhan sesuai. Dari segi kelengkapan materi sudah sesuai, dari segi keluasan materi belum maksimal dan kedalaman materi masih kurang sesuai. Kesesuaian materi dengan kurikulum merupakan syarat mutlak yang harus dipenuhi untuk memberi kemudahan dalam mencapai tujuan pembelajaran yang telah ditetapkan

2. Konsep dan definisi harus dirumuskan dengan tepat (well defined) untuk mendukung tercapainya KI dan KD.

Konsep dan definisi yang ditampilkan dalam buku teks terbitan Pusat Kurikulum dan Perbukuan, Balitbang, Kemendikbud 2017 yang dianalisis ini, dapat dikatakan telah mendukung tercapainya KI dan KD kurikulum 2013. Materi-materi yang disajikan dalam buku teks ini mampu merangsang siswa untuk dapat 
mengungkapkan ide dan gagasannya serta memberikan kesempatan kepada siswa untuk dapat menelaah sendiri materi yang telah dipaparkan dalam buku teks.

b. Akurasi Prosedur

Prosedur- prosedur yang dirumuskan dalam buku teks terbitan Pusat Kurikulum dan Perbukuan, Balitbang, Kemendikbud 2017 ini dapat dikatakan sudah cukup baik. Bisa kita lihat pada halaman 127 dengan materi menggambar poster. Langkah-langkah atau prosedur dalam menggambar poster dipaparkan secara jelas dan runtut. Hal ini tentu dapat menghindarkan siswa untuk melakukan kesalahan sistematis pada setiap materi yang diajarkan dalam buku teks.

c. Akurasi Contoh, Fakta, dan Ilustrasi Contoh, fakta, dan ilustrasi yang ditampilkan dalam buku teks terbitan Pusat Kurikulum dan Perbukuan, Balitbang, Kemendikbud 2017 ini telah disajikan secara akurat. Hal ini dapat dibuktikan dari materi-materi yang disajikan pada setiap bab. Contoh terdapat pada halaman 3

d. Akurasi Sosial

Soal-soal yang disajikan pada buku teks ini telah disusun secara akurat untuk mendukung siswa dalam menguasai materi yang telah dibelajarkan.Sebagai contoh dapat kita lihat pada latihan mandiri

\section{c. Materi Pendukung Pembelajaran}

1. Kesesuaiannya dengan perkembangan ilmu dan teknologi.
Materi (termasuk contoh, latihan, dan daftar pustaka) yang terdapat dalam buku teks harus sesuai dengan perkembangan ilmu dan teknologi.

2. Keterkinian Fitur,contoh, dan rujukan. Fitur (termasuk uraian, contoh, dan latihan) mencerminkan peristiwa atau kondisi terkini. Keterkinian ini terlihat pada sumber atau rujukan yang digunakan. Pada umumnya rujukan yang layak digunakan dalam buku teks maksimal menggunakan rujukan lima tahun terakhir.

\section{Penalaran (Reasoning)}

Penalaran ini berperan pada saat siswa harus membuat kesimpulan. Oleh karena itu materi dalam buku teks perlu memuat uraian, contoh, tugas, pertanyaan, atau soal latihan yang mendorong peserta didik untuk secara runtut membuat kesimpulan yang sahih (valid). Materi dapat pula memuat soal- soal terbuka (openended problem), yaitu soal-soal yang menuntut siswa untuk memberikan jawaban atau strategi penyelesaian yang bervariasi.

Pemecahan Masalah (Problem Solving) Untuk menumbuhkan kreativitas siswa, sajian materi dalam buku teks perlu memuat beragam strategi dan latihan pemecahan masalah. Pemecahan masalah meliputi memahami masalah, merancang model, memeriksa hasil (mencari solusi 
yang layak), dan menafsirkan solusi yang diperoleh.

\section{Keterkaitan Antar konsep}

Keterkaitan antar-konsep dalam buku teks dapat dimunculkan dalam uraian atau contoh. Hal ini dimaksudkan untuk membantu peserta didik dalam membangun jaringan pengetahuan yang utuh. Selain itu, perlu juga ditunjukkan keterkaitan antara pelajaran satu dan pelajaran atau keterkaitan antara materi yang sedang dipelajari dan kehidupan sehari-hari agar siswa menyadari manfaat materi tersebut dalam kehidupan.

5. Komunikasi (Writeand Talk)

Materi dalam buku teks hendaknya memuat contoh atau latihan untuk mengomunikasikan gagasan, baik secara secara tertulis maupun secara lisan, untuk memperjelas keadaan atau masalah yang sedang dipelajari atau dihadapi.

\section{Penerapan (Aplikasi)}

Materi dalam buku teks hendaknya memuat uraian, contoh, atau soalsoal yang menjelaskan

penerapan suatu konsep dalam kehidupan sehari-hari. Hal ini dimaksudkan agar siswa dapat menerapkan dalam kehidupan nyata setiap konsep yang dipelajari.
7. Kemenarikan Materi

Materi dalam buku teks hendaknya memuat uraian, strategi, gambar, foto, sketsa, cerita sejarah, contoh, atau soal- soal menarik yang dapat menimbulkan minat siswa untuk mengkaji lebih jauh. Apabila siswa tertarik terhadap materi yang dipelajari, ia akan terangsang untuk mempelajarinya lebih jauh.

\section{Mendorong}

Untuk Mencari Informasi Lebih Jauh Materi dalam buku teks hendaknya memuat tugas-tugas yang mendorong siswa untuk memperoleh informasi lebih lanjut dari berbagai sumber lain seperti internet, buku, artikel, dsb.

9. Materi pengayaan (enrichment)

Materi dalam buku teks sebaiknya menyajikan uraian, contoh-contoh, atau soal-soal pengayaan yang berkaitan dengan topik yang dibicarakan sehingga sajian materinya lebih luas atau lebih dalam daripada materi yang dituntut KD. Dengan pengayaan ini, diharapkan siswa mempunyai kompetensi yang lebih luas dan kaya.

\section{Kesimpulan}

Berdasarkan hasil analisis
kelayakan isi yang telah dilakukan
terhadap buku teks pelajaran Seni Budaya
yang diterbitkan oleh Pusat Kurikulum dan


Perbukuan, Balitbang, Kemendikbud 2017. dengan judul "Seni Budaya untuk SMP/ MTs Kelas VIII Kurikulum 2013” yang disusun oleh Eko Purnomo, dkk., buku teks ini layak digunakan sebagai bahan ajar untuk proses pembelajaran di sekolahsekolah.

Analisis kelayakan isi buku teks pelajaran Seni Budaya terbitan Pusat Kurikulum dan Perbukuan, Balitbang, Kemendikbud 2017 ini sesuai dengan instrument yang telah ditetapkan oleh BNSP, meliputi Kesesuain Uraian Materi dengan KI dan KD dalam kurikulum 2013, Keakuratan Materi, dan Materi Pendukung Pembelajaran. Buku teks terbitan Pusat Kurikulum dan Perbukuan, Balitbang, Kemendikbud 2017 ini memang dapat dikatakan sudah memenuhi kelayakan isi. Namun dalam hal keluasan materi Buku teks terbitan Pusat Kurikulum dan Perbukuan, Balitbang, Kemendikbud 2017 ini tergolong masih kurang perlu di tambah konten materinya..

\section{Saran}

Berdasarkan hasil analisis terhadap kelayakan isi buku teks pelajaran Bahasa Indonesia Kelas VII SMP/MTs Kurikulum 2013 terbitan Pusat Kurikulum dan Perbukuan, Balitbang, Kemendikbud 2017, peneliti menyarankan sebagai berikut.

\section{Bagi Guru}

Guru dapat menggunakan buku guru dan buku teks (buku siswa) pelajaran Seni Budaya terbitan Pusat Kurikulum dan Perbukuan, Balitbang, Kemendikbud 2017 ini sebagai buku acuan utama dalam proses belajar mengajar sehingga dapat mempermudah guru dalam menyampaikan materi yang lebih fokus dan terarah pada kurikulum yang berlaku pada saat ini.

2. Bagi siswa

Siswa dapat menggunakan buku teks Seni budaya terbitan Pusat Kurikulum dan Perbukuan, Balitbang, Kemendikbud 2017 sebagai buku acuan utama yang berkualitas untuk belajar di rumah maupun di sekolah sehingga mempercepat proses pemahaman materi dan pencapaian nilai yang maksimal.

\section{Daftar Pustaka}

Departemen Pendidikan Nasional. 2015. Peraturan Pemerintah Republik Indonesia Nomor 19 Tahun 2015 Tentang Standar Nasional Pendidikan. Jakarta: Menteri Pendidikan Nasional. 2005. Peraturan Menteri

Pendidikan Nasional Nomor 11 Tahun 2005 tentang Buku Teks Pelajaran. Jakarta: Menteri Pendidikan Nasional.

Bungin, Burhan. 2011. Metodologi Penelitian Kuantitatif. Jakarta: Kencana Predana Media . 2004. Petunjuk Kualitas Buku. Jakarta: Menteri Pendidikan Nasional 2005.Peraturan Pemerintah Nomor 19 Tahun 2005 tentang Standar Nasional Pendidikan, Pasal 43 ayat 5. Jakarta: Menteri Pendidikan Nasional 
Syamsualam, Irfan, Sumiati Patimari, Kelayakan Isi Buku Teks Seni Budaya Kurikulum 2013

SMP/MTS Kelas VIII Ditinjau Dari Aspek Pembelajaran Seni Rupa, hlm. 46-53

Eriyanto. 2011. Analisis Isi: Pengantar Metodologi untuk Penelitian Ilmu

Komunikasi dan Ilmu-ilmu Sosial

Lainnya. Jakarta: Kencana Prenada. 